KAPL-P-000153

(K97022)

CONF-9704192--

\title{
THERMOELECTRIC PROPERTIES OF ZnSb FILMS GROWN BY MOCVD
}

R. Venkatasubramanian, (A.C. Pezzi)

April 1997

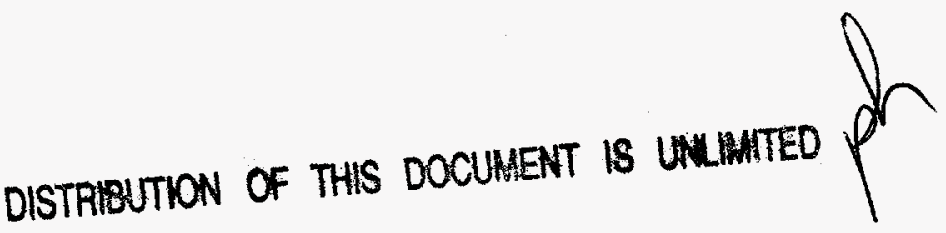

\section{NOTICE}

This report was prepared as an account of work sponsored by the United States Government. Neither the United States, nor the United States Department of Energy, nor any of their employees, nor any of their contractors, subcontractors, or their employees, makes any warranty, express or implied, or assumes any legal liability or responsibility for the accuracy, completeness or usefulness of any information, apparatus, product or process disclosed, or represents that its use would not infringe privately owned rights. 


\section{DISCLAIMER}

This report was prepared as an account of work sponsored by an agency of the United States Government. Neither the United States Governmeat nor any agency thereof, nor any of their employees, makes any warranty, express or implied, or assumes any legal liability or responsibility for the accuracy, completeness, of usefulness of any information, apparatus, product, or process disclosed. or represents that its use would not infiringe privately owned rights. Refereace berein to any specific commercial product, process, or service by trade name, trademark, imanufactures, or otherwise does not necessarily constitute or imply its endorsement, recommendation, or favoring by the United States Governmeat or any agency thereof. The views and opinions of authors expressed herein do not necessarily state or reflect those of the United States Government or any agency thereof. 


\section{DISCLAIMER}

Portions of this document may be illegible in electronic image products. Images are produced from the best available original document. 


\title{
Thermoelectric Properties of $\mathrm{ZnSb}$ Films Grown by MOCVD
}

\author{
R. Venkatasubramanian, E. Watko and T. Colpitts \\ Research Triangle Institute, Research Triangle Park, NC 27709, USA.
}

\section{Abstract}

The thermoelectric properties of metallorganic chemical vapor deposited (MOCVD) ZnSb films are reported. The growth conditions necessary to obtain stoichiometric $\mathrm{ZnSb}$ films and the effects of yarious growth parameters on the electrical conductivity and Seebeck coefficients of the films are described. The as-grown $\mathrm{ZnSb}$ films are p-type. It was observed that the growth of thicker $\mathrm{ZnSb}$ films lead to improved carrier mobilities and lower free-carrier concentrations. The Seebeck coefficient of $\mathrm{ZnSb}$ films was found to rise rapidly at approximately 160 to $170^{\circ} \mathrm{C}$, with peak Seebeck coefficients as high as $470 \mu \mathrm{V} / \mathrm{K}$ at $220^{\circ} \mathrm{C}$. The various growth conditions, including the use of intentional dopants, to improve the Seebeck coefficients at room temperature and above, are discussed. A short annealing of the $\mathrm{ZnSb}$ films at temperatures of $\sim 200^{\circ} \mathrm{C}$ resulted in reduced free-carrier levels and higher Seebeck coefficients at $300 \mathrm{~K}$. Finally, ZT values based on preliminary thermal conductivity measurements using the 3- $\omega$ method are reported.

\section{Introduction}

Thin film $\mathrm{ZnSb}$, with a stoichiometry of $\mathrm{Zn}: \mathrm{Sb}=1: 1$, could be a material with a potentially high ZT for power generation applications. $\mathrm{ZnSb}$, an intermetallic compound, tends to offer a high Seebeck coefficient compared to other phases of the alloy probably due to the ionic character of the compound. Thin films of $\mathrm{ZnSb}$ grown by the ionized cluster beam (ICB) process have indicated Seebeck coefficients as high as $600 \mu \mathrm{V} / \mathrm{K}$ at $550 \mathrm{~K}$ [1]. These $\mathrm{ZnSb}$ films had appreciable electrical conductivity, as high as $5 E 2$ $\mathrm{ohm}^{-1} \mathrm{~cm}^{-1}$. The $\mathrm{ZnSb}$ thin-films were always $\mathrm{p}$ type with modest carrier mobilities $-22 \mathrm{~cm}^{2} / \mathrm{V}$ sec. Even so, assuming that the thermal conductivity of the $\mathrm{ZnSb}$ thin films are comparable to bulk polycrystalline samples, a ZT of -5 was estimated at $520 \mathrm{~K}$ [1]. In this paper we report that $\mathrm{ZnSb}$ films grown by MOCVD, with a stoichiometry of $\mathrm{Zn}: \mathrm{Sb}=1: 1$, offer high Seebeck coefficients and also provide some experimental justification of the assumption that the thermal conductivity of the thinfilms are indeed comparable to bulk $\mathrm{ZnSb}$ crystals.

\section{MOCVD Growth of $\mathrm{ZnSb}$}

We chose to grow the $\mathrm{ZnSb}$ thin films on semiinsulating GaAs substrates using diethylzinc (DEZn) and trisdimethylaminoantimony (TDMASb). The semi-insulating GaAs substrates were chosen to enable the measurement of resistivity by the van der Pauw Hall method and the determination of the inplane Seebeck coefficients of the $\mathrm{ZnSb}$ epitaxial layers. We found that the stoichiometry was reproducible for a given set of flow rates of DEZn and TDMASb and also preferably over a wide ratio of the flow rates of these precursors. There was considerable variation of the $\mathrm{Zn}: \mathrm{Sb}$ ratio in $\mathrm{Zn}_{\mathrm{x}} \mathrm{Sb}_{1-\mathrm{x}}$ films with flow-rates of DEZn and TDMASb depending on the growth temperature. The stoichiometry values were determined by energy dispersive $\mathrm{X}$-Ray analysis (EDAX) and where results are accurate to within a few percent.

\section{Properties of ZnSb Films}

Here, we first discuss the electrical transport properties of $\mathrm{ZnSb}$ films measured by Hall-effect. Next the Seebeck coefficient $(\alpha)$ measured in the films at $300 \mathrm{~K}$, the variation of $\alpha$ with temperature and the effect of various growth conditions on $\alpha$ are discussed. Then we discuss the thermal conductivity values in a select set of films, measured by the 3- $\omega$ method. Finally, the potential $\mathrm{ZT}$ values in some thick $\mathrm{ZnSb}$ films are indicated at $-175^{\circ} \mathrm{C}$.

\section{Electrical Transport Properties}

The as-grown $\mathrm{ZnSb}$ films on GaAs were found to be always p-type, similar to the $\mathrm{ZnSb}$ films [1] grown by the ICB process. Shown in Table 1 is the effect of increased layer thickness of the epitaxial $\mathrm{ZnSb}$ film on lower residual p-doping level and higher hole mobility. The fairly significant reduction in residual doping level in conjunction with increase in mobility, up to $-0.75 \mu \mathrm{m}$, is probably a result of decreasing lattice-mismatch (with respect to GaAs substrate) related defects in the $\mathrm{ZnSb}$ films. Growth of films with thickness greater than $-1.35 \mu \mathrm{m}$ was hampered by the limited growth rates of these films, with notyet-fully-optimized growth conditions. We note that the best carrier mobility $\left(-23.5 \mathrm{~cm}^{2} / \mathrm{V} \mathrm{sec}\right)$ of the 
micron-thick film is comparable to the value of 22.8 $\mathrm{cm}^{2} N$.sec, reported in $\mathrm{ZnSb}$ films grown by the ICB process. The electrical conductivities of the films are in the range of $1 \mathrm{E} 3 \mathrm{ohm}^{-1} \mathrm{~cm}^{-1}$, about a factor of two higher than those reported in $\mathrm{ZnSb}$ films by the ICB process [1].

The high residual p-doping level in the $\mathrm{ZnSb}$ films, even with thicker films, is thought to be related to native $\mathrm{Sb}$ vacancies. $\mathrm{Te}$, a Group-VI atom, is expected to occupy the $\mathrm{Sb}$ site and reduce the residual p-doping level. In fact, there has been a published work on the use of Te doping in bulk CdSb to improve the thermoelectric properties [4]. So we investigated the use of Te doping in $\mathrm{ZnSb}$ films. The initial results are shown in Table 2.

Table 1 Effect of ZnSb Layer Thickness on Residual Doping Level and Hole Mobility at $25^{\circ} \mathrm{C}$.

\begin{tabular}{|cccc|}
\hline Sample \# & $\begin{array}{c}\text { Thickness }(\mathbf{t}) \\
(\mu \mathbf{m})\end{array}$ & $\begin{array}{c}\text { Doping Level } \\
\left(\mathbf{c m}^{-3}\right)\end{array}$ & $\begin{array}{c}\text { 300K Carrier } \\
\text { Mobility } \\
\left(\mathbf{c m}^{\mathbf{2}} / \mathbf{V s e c}\right)\end{array}$ \\
\hline \hline & & & \\
$7-125$ & 0.13 & $8.5 \mathrm{E} 20$ & 13.4 \\
$7-127$ & 0.5 & $5.4 \mathrm{E} 20$ & 15.5 \\
$7-234$ & 0.55 & $4.8 \mathrm{E} 20$ & 17.1 \\
$7-235$ & 0.50 & $4.5 \mathrm{E} 20$ & 18.6 \\
$7-236$ & 0.75 & $3.3 \mathrm{E} 20$ & 20.4 \\
$7-237$ & 0.75 & $3.4 \mathrm{E} 20$ & 20.6 \\
$7-239$ & 1.1 & $2.7 \mathrm{E} 20$ & 20.8 \\
$7-242$ & 1.2 & $2.9 \mathrm{E} 20$ & 19.0 \\
$7-247$ & 1.05 & $2.7 \mathrm{E} 20$ & 23.5 \\
$7-248$ & 0.9 & $4.0 \mathrm{E} 20$ & 17.7 \\
\hline
\end{tabular}

Table.2 Effect of Te Doping on Properties of ZnSb Films.

\begin{tabular}{|c|c|c|c|c|c|}
\hline Sample \# & $\begin{array}{c}\text { Thickness } \\
t(\mu \mathrm{m})\end{array}$ & $\begin{array}{c}\text { Te-Doping } \\
\text { (Torr) }\end{array}$ & $\begin{array}{c}\text { X-Ray } \\
\text { Data }\end{array}$ & $\underset{\left(\mathrm{cm}^{-3}\right)}{\mathbf{p}}$ & $\left(\mathrm{cm}^{2} / \mathrm{Vsec}^{\mu}\right)$ \\
\hline $7-235$ & 0.5 & --- & $\begin{array}{c}\text { Single } \\
\text { Crystalline }\end{array}$ & $4.5 \mathrm{E} 20$ & 18.6 \\
\hline $7-244$ & 0.5 & $3.5 \times 10^{-4}$ & $\begin{array}{c}\text { Single } \\
\text { Crystalline }\end{array}$ & $3.6 \mathrm{E} 20$ & 20.0 \\
\hline $7-240$ & 0.33 & $5.5 \times 10^{-3}$ & Poly & $2.0 \mathrm{E} 18$ & 0.76 \\
\hline $7-245$ & 0.47 & $7.0 \times 10^{-4}$ & $\begin{array}{c}\text { Single } \\
\text { Crystalline }\end{array}$ & 3.1E20 & 16.2 \\
\hline
\end{tabular}

For layer thickness of $\sim 0.5 \mu \mathrm{m}$, we noticed a fairly small drop in residual doping level with small partial pressures of the Te dopant during growth. At high concentrations of the Te dopant, we observed that the $\mathrm{ZnSb}$ films become polycrystalline (from $\mathrm{x}$-ray data) and even though the residual doping falls dramatically over two orders of magnitude, the hole mobility becomes very low from the polycrystalline nature of the film.

\section{Seebeck Coefficients in ZnSb Films}

The Seebeck coefficients $(\alpha)$ in the $\mathrm{ZnSb}$ films were typically measured between $25^{\circ} \mathrm{C}$ to $200^{\circ} \mathrm{C}$. Shown in Figure 1 is the variation of $\alpha$ with temperature, for 
two ZnSb samples of different thickness (see Table 1). We noted that the thicker film, due to the lower residual doping level, offers a significantly higher $\alpha$ from $25^{\circ} \mathrm{C}$ through $200^{\circ} \mathrm{C}$.

We also noted the rather sharp rise in $\alpha$ near $175^{\circ} \mathrm{C}$, for both samples. This is very similar to the observed $\alpha$ vs. I behavior of $\mathrm{ZnSb}$ films grown by the ICB process [1]. The near-constant Seebeck coefficients between $25^{\circ} \mathrm{C}$ to $-175^{\circ} \mathrm{C}$ is indicative of nearconstant electrical conductivity and absence of any chemical changes, as experimentally noted in the work of $\mathrm{ZnSb}$ films by ICB. We believe that the $\mathrm{ZnSb}$ films are stable till $\sim 175^{\circ} \mathrm{C}$; above this temperature some chemical changes may occur in the films leading to a sharp increase in $\alpha$. This was confirmed partly by the significant reduction in carrier concentration and increase in resistivity of $\mathrm{ZnSb}$ films at $25^{\circ} \mathrm{C}$, after an exposure to $-200^{\circ} \mathrm{C}$. This data is summarized in Table 3.

Thus, the $\mathrm{ZnSb}$ films are stable up to $-175^{\circ} \mathrm{C}$ and apparently offer significantly high Seebeck coefficients between $25^{\circ} \mathrm{C}$ to $\sim 175^{\circ} \mathrm{C}$, in spite of the free-carrier levels considered here.

\section{Thermal Conductivity of $\mathrm{ZnSb}$ Films}

Some preliminary measurements of the thermal conductivity $(\mathrm{K})$ of $\mathrm{ZnSb}$ films were carried out using the 3- $\omega$ method $[2,3]$. Shown in Table 4 are the $K$ values at $300 \mathrm{~K}$ for $\mathrm{ZnSb}$ films, as a function of layer thickness (or carrier concentration) and the effect of Te doping. It is interesting to note that, for as-grown films, the thermal conductivity decreases at lower carrier levels suggesting that a significant portion of the thermal conductivity could be from transport of heat by carriers. It is worth noting that the Sample 7-240, which had the lowest free-carrier level and turned polycrystalline from excessive Tedoping, offers the lowest thermal conductivity at $25^{\circ} \mathrm{C}$. This is consistent with the polycrystalline grain-boundary scattering of phonons as well as lower contribution of carrier transport of heat to thermal conductivity.

As noted in the previous section, the Seebeck coefficient of $\mathrm{ZnSb}$ films remains fairly stable up to $175^{\circ} \mathrm{C}$ and so it was important to measure thermal conductivity of the films at $175^{\circ} \mathrm{C}$, to estimate $\mathrm{ZT}$ values. Hence, we carried out 3- $\omega$ measurements on a set of samples and the data is shown in Table 5.

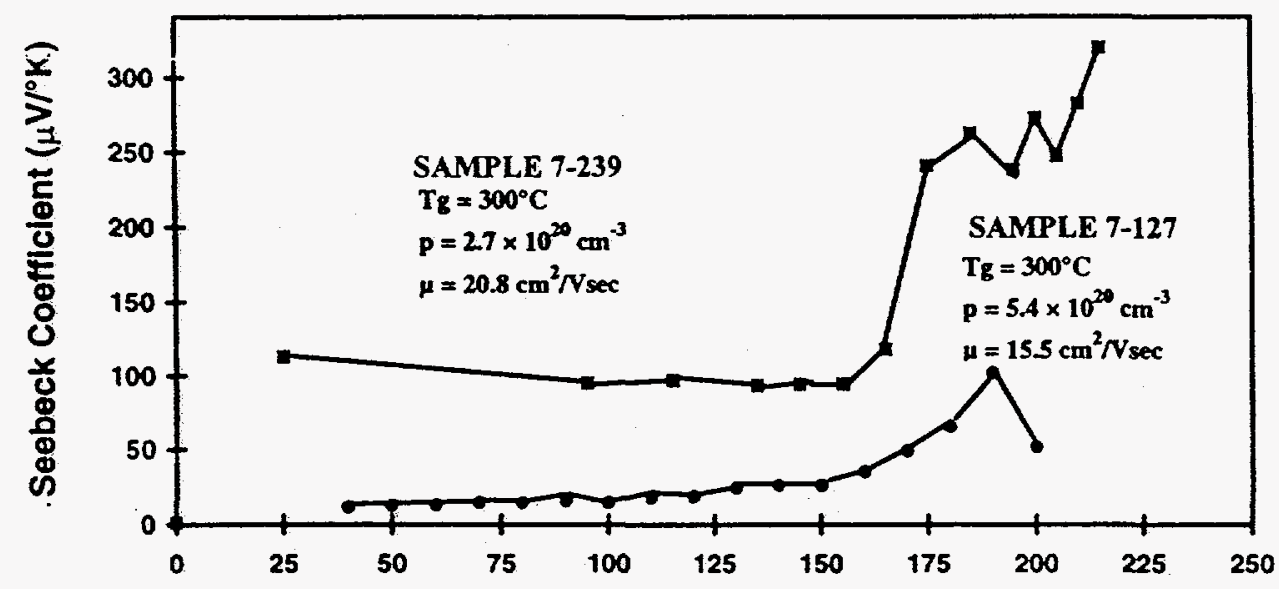

Temperature $\left({ }^{\circ} \mathrm{C}\right)$

Figure 1 Effect of layer thickness and temperature on Seebeck coefficients of $\mathrm{ZnSb}$ films. 
Table 3 Hall-Data of $\mathrm{ZnSb}$ Samples Before and After $200^{\circ} \mathrm{C}$ Exposure During Seebeck Coefficient Measurement.

\begin{tabular}{|c|c|c|c|c|c|c|c|}
\hline \multirow[t]{2}{*}{$\begin{array}{c}\text { Sample } \\
\#\end{array}$} & \multirow[t]{2}{*}{$\begin{array}{c}\text { Thickness } \\
(\mu \mathrm{m})\end{array}$} & \multicolumn{3}{|c|}{$\begin{array}{c}\text { Before } \\
200^{\circ} \mathrm{C} \text { Exposure }\end{array}$} & \multicolumn{3}{|c|}{$\begin{array}{c}\text { After } \\
\text { 200 }^{\circ} \mathrm{C} \text { Exposure }\end{array}$} \\
\hline & & $\underset{\left(\mathrm{cm}^{2} / \mathrm{vs}\right)}{\stackrel{\mu}{2}}$ & $\underset{\left(\mathrm{cm}^{-3}\right)}{P}$ & $\begin{array}{l}\text { Resistivity } \\
\text { (ohm-cm) }\end{array}$ & $\underset{\left(\mathrm{cm}^{2} / \mathrm{vs}\right)}{\mu}$ & $\underset{\left(\mathrm{cm}^{-3}\right)}{\mathrm{P}}$ & $\begin{array}{l}\text { Resistivity } \\
\text { (ohm-cm) }\end{array}$ \\
\hline $7-125-b$ & 0.03 & 13.4 & 8.5E20 & $5.5 \mathrm{E}-4$ & 13.1 & $4.2 \mathrm{E} 20$ & $1.1 \mathrm{E}-3$ \\
\hline $7-127$ & 0.5 & 15.5 & $5.4 \mathrm{E} 20$ & $7.4 \mathrm{E}-4$ & 15.7 & $3.0 \mathrm{E} 20$ & $1.3 \mathrm{E}-3$ \\
\hline $7-127-a$ & 0.5 & 9.0 & $4.8 \mathrm{E} 20$ & $1.45 \mathrm{E}-3$ & 9.3 & $2.5 \mathrm{E} 20$ & $2.7 \mathrm{E}-3$ \\
\hline
\end{tabular}

Table 4 Thermal Conductivity of ZnSb Films at $25^{\circ} \mathrm{C}$ Determined by the 3- $\omega$ Method.

\begin{tabular}{|ccccc|}
\hline Sample \# & $\begin{array}{c}\text { Thickness } \\
(\mu \mathrm{m})\end{array}$ & $\begin{array}{c}\text { Carrier } \\
\text { Concentration } \\
\left(\mathbf{c m}^{-3}\right)\end{array}$ & $\begin{array}{c}\text { Te } \\
\text { Doping }\end{array}$ & $\begin{array}{c}\mathbf{K} \\
(\mathbf{W} / \mathbf{c m}-\mathbf{K})\end{array}$ \\
\hline \hline $7-248$ & 0.9 & $4.0 \mathrm{E} 20$ & - & 0.033 \\
$7-247$ & 1.05 & $2.4 \mathrm{E} 20$ & - & 0.011 \\
$7-244$ & 0.5 & $3.6 \mathrm{E} 20$ & Yes & 0.083 \\
$7-246$ & 1.1 & $3.3 \mathrm{E} 20$ & Yes & 0.010 \\
$7-240$ & 0.33 & $2.0 \mathrm{E} 18$ & Yes; Polycrystalline & 0.008 \\
\hline
\end{tabular}

Table 5 Thermal Conductivity of $\mathrm{ZnSb}$ Films at $150^{\circ} \mathrm{C}$, Determined by the 3- $\omega$ Method.

\begin{tabular}{|ccccc|}
\hline Sample \# & $\begin{array}{c}\text { Thickness } \\
(\mu \mathbf{m})\end{array}$ & $\begin{array}{c}\text { Te } \\
\text { Doping }\end{array}$ & $\begin{array}{c}\mathbf{K}_{\mathbf{3 m m}} \\
(\mathbf{W} / \mathbf{c m K})\end{array}$ & $\begin{array}{c}\mathbf{K}_{\mathbf{4 2 3}} \\
\mathbf{W} / \mathbf{c m K})\end{array}$ \\
\hline \hline $7-248$ & 0.9 & -- & 0.033 & 0.021 \\
$7-247$ & 1.05 & -- & 0.011 & 0.009 \\
$7-244$ & 0.5 & Yes & 0.083 & 0.034 \\
$7-240$ & 0.33 & Yes; Polycrystalline & 0.008 & 0.020 \\
\hline
\end{tabular}

For as-grown films, the thermal conductivity $(\mathrm{K})$ falls slowly in going from $25^{\circ} \mathrm{C}$ to $150^{\circ} \mathrm{C}$. This is consistent with the observed variation of $\mathrm{K}$ with temperature in CdSb bulk crystals [4]. However, in the case of Te-doped $\mathrm{ZnSb}$ films, we noticed a significant drop in thermal conductivity in going from $25^{\circ} \mathrm{C}$ to $150^{\circ} \mathrm{C}$. This is a potentially useful result for higher $\mathrm{ZT}$ values of Te-doped $\mathrm{ZnSb}$ films at higher temperatures, considering that Te-doped $\mathrm{ZnSb}$ films also show near constancy of $\alpha$ with temperatures between $25^{\circ} \mathrm{C}$ to $175^{\circ} \mathrm{C}$. We also noted that the polycrystalline $\mathrm{ZnSb}$ film shows an increasing $\mathrm{K}$ with temperature and this is consistent with reduced phonon-scattering by grain boundaries 
at higher temperatures. It is important to note that typical $\mathrm{K}$ values of $\mathrm{ZnSb}$ films at $\sim 150^{\circ} \mathrm{C}$ are $\sim 0.01$ to $0.03 \mathrm{~W} / \mathrm{cm} \mathrm{K}$, in reasonable agreement with $\sim 0.01$ $\mathrm{W} / \mathrm{cm} \mathrm{K}$ seen in bulk $\mathrm{ZnSb}$ crystals at $-250^{\circ} \mathrm{C}[1]$. This is indicative of the validity of the $K$ values determined by the 3- $\omega$ method in thin-films of wellknown materials.

\section{$\mathrm{ZT}$ values of $\mathrm{ZnSb}$ films}

With the measurement of the Seebeck coefficient and thermal conductivity of $\mathrm{ZnSb}$ films at $-150^{\circ} \mathrm{C}$, well below the possible onset of dissociation and with the assumption that the electrical conductivity of $\mathrm{ZnSb}$ films do not change appreciably between $25^{\circ} \mathrm{C}$ and $150^{\circ} \mathrm{C}$, we have indicated the $\mathrm{ZT}$ value of the best $\mathrm{ZnSb}$ film at $150^{\circ} \mathrm{C}$ in Table 6.

Sample $7-248$ indicates a ZT of $\sim 3.2$ at $150^{\circ} \mathrm{C}$. At $25^{\circ} \mathrm{C}$, this sample has a $\mathrm{ZT}$ of $\sim 0.4$. This represents an important milestone for the potential performance of thin-film $\mathrm{ZnSb}$, with a well-controlled stoichiometry of $\mathrm{Zn:Sb}=1: 1$, grown by MOCVD.

\section{Summary}

We have demonstrated that $\mathrm{ZnSb}$ single-crystalline films with a stoichiometry of $\mathrm{Zn:Sb}=1: 1$ can be grown by MOCVD. The residual doping level in these films was rather high, although decreasing monotonically from $8.5 \mathrm{E} 20 \mathrm{~cm}^{-3}$ for layer thickness of $0.13 \mu \mathrm{m}$ to $2.7 \mathrm{E} 20 \mathrm{~cm}^{-3}$ for layer thickness of 1.1 $\mu \mathrm{m}$. The preliminary values of Seebeck coefficients of these films were found to be as high as $372 \mu \mathrm{V} / \mathrm{K}$ at $\sim 150^{\circ} \mathrm{C}$. With the evaluation of the Seebeck coefficient of $\mathrm{ZnSb}$ thin films, the measurement of thermal conductivity by the 3- $\omega$ method and assuming that the electrical resistivity at $150^{\circ} \mathrm{C}$ remains about the same as that measured at $25^{\circ} \mathrm{C}$, we estimate a $\mathrm{ZT}$ of -3.2 at $150^{\circ} \mathrm{C}$ for a $\mathrm{ZnSb}$ film of $\sim 1.0 \mu \mathrm{m}$-thickness. These results are of interest to efficient low-temperature, low-grade-heat, thermoelectric power generation.

\section{References}

1. T. Koyanagi et.al, Proc. of the XII International Conf. on Thermoelectrics, Yokohama, Japan, 340(1994).

2. D.G. Cahill and R.O. Pohl, Phys. Rev. B, 35, 4067 (1987) and D.G. Cahill, H.E. Fischer, T. Klitsner, E.T. Swartz, and R.O. Pohl, J. Vac. Sci. and Technol. A7, 1259 (1989).

3. D.G. Cahill, M. Katiyar, and J.R. Abelson, Phys. Rev. B, 50, 6077 (1994).

4. S.V. Airapetyants, Thermoelectric Properties of Semiconductors, Ed. by V.A. Kutasov, Consultants Bureau, New York, 1964.

Table 6 Property of best $\mathrm{ZnSb}$ Film at $150^{\circ} \mathrm{C}$.

\begin{tabular}{ccccccc}
\hline $\begin{array}{c}\text { SAMPLE } \\
\#\end{array}$ & $\begin{array}{c}\text { THICKNESS } \\
(\mu \mathrm{m})\end{array}$ & $\begin{array}{c}\text { Te } \\
\text { DOPING }\end{array}$ & $\begin{array}{c}\text { POWER } \\
(\mu \mathrm{V} / \mathrm{K})\end{array}$ & $\begin{array}{c}\text { THERMAL } \\
\left(\mu \mathrm{W} / \mathbf{c m}^{2} \mathbf{K}^{2}\right)\end{array}$ & $\begin{array}{c}\text { TONDUCTIVITY } \\
\mathbf{K}_{\mathbf{4 2 3}}(\mathbf{m W} / \mathbf{c m K})\end{array}$ & $\mathbf{Z T}^{+}$ \\
\hline $7-248$ & 0.9 & -- & 372.4 & 159.4 & 20.5 & 3.28 \\
\hline
\end{tabular}

+ Power factor and $\mathrm{ZT}$ are calculated assuming resistivity value at $423 \mathrm{~K}$ is about the same as at $300 \mathrm{~K}$. 